Throughout these years of developmental work, Kapitza had visited Russia almost every summer. During these visits he gave lectures and advised on the construction of new institutes, and it was known that he had at one time been offered the directorship of an institute in Russia, but Kapitza himself considered that conditions in the U.S.S.R. were not favourable for the development of his work. It came, therefore, as a shock to his colleagues to learn in October that Kapitza's return passport had been refused, and that he had been ordered to begin the construction of a new laboratory in Russia. The reasons underlying this action may be inferred from the following statement from the Soviet Embassy which appeared in the News-Chronicle:- "Peter Kapitza is a citizen of the U.S.S.R., educated and trained at the expense of his country. He was sent to England to continue his studies and research work ... Now the time has arrived when the Soviet urgently needs all her scientists. So when Prof. Kapitza came home last summer he was appointed as director of an important now research station which is being built at Moscow". This commandeering of Kapitza's services on behalf of the U.S.S.R. ignores the personal and psychological factors involved, as was pointed out by Lord Rutherford in a letter to The Times of April 29. A man of Kapitza's highlystrung type must inevitably be profoundly disturbed by a sudden frustration of years of work ; and it comes as no surprise to his friends to learn from reliable sources that his health has already been seriously impaired by anxiety and strain. The right of the Soviet to retain Kapitza in his native country can scarcely be questioned, but from the point of view of international science we venture to express the hope that he may be permitted to return to Cambridge to complete the investigations with the remarkable plant designed by him and installed in the Royal Society Mond Laboratory at the University.

\section{Retirement of Sir Peter Chalmers Mitchell}

LAST summer it was announced that Sir Peter Chalmers Mitchell was to retire from the post he had held for more than thirty years as secretary of the Zoological Society of London (see NATure, Aug. 25, 1934, p. 280). At the annual meeting of the Society held on April 29, Sir Peter formally vacated the secretaryship and his successor, Prof. Julian S. Huxley, took his place. Sir Henry Mahon and Prof. J. Stanley Gardiner presented Sir Peter with his portrait, painted by Mr. William Nicholson, on behalf of some 1,250 members of the Society ; very appropriately, the background of the portrait includes a map of the Whipsnade estate, with the development of which Sir Peter's name will always be associated. The response to the appeal for the portrait was so generous that it has been possible to send each subscriber a reproduction in colour of the portrait and also to present to Sir Peter a personal memento. The Duke of Bedford, president of the Zoological Society, in moving a resolution of thanks to Sir Peter for his many years of active and inspiring service to the Society and to science, stated that whereas in 1902 the Society's Gardens in Regent's Park had 69,500 visitors, in 1934 the number had increased to $1,690,000$, while the Society's high reputation as a scientific body has been similarly enhanced. The Society has been a pioneer, under the guidance of Sir Peter Chalmers Mitchell, in the improvement of the conditions under which animals are kept in captivity. On the more strictly scientific side, mention should also be made of the valuable investigations carried out by the succession of anatomists, pathologists and other workers who have been encouraged by Sir Peter to study the Society's collections.

\section{King George's Jubilee Trust}

No social change of our time is more significant than the way in which leisure has ceased to be the privilege of a few and become the concern, if not indeed the lot, of the many. In the problems which leisure now presents, there is none more serious and pressing than those which it presents in adolescence. The Jubilee Trust inaugurated by the Prince of Wales at St. James's Palace on March 1 is designed specially to deal with such problems, and a further reference to its objects was made in an appeal broadcast by His Royal Highness on April 12. The main objects of the Trust are to provide more and better facilities for the recreation and guidance of the younger generation, to encourage the cultivation of abilities, craftsmanship and all those outdoor interests and activities which make for mental and physical fitness. The Trust will assist, strengthen and extend the work of the many voluntary organisations in existence, the work of which is to promote the welfare of the boys and girls of Great Britain. It will enable similar movements to be started in places at present untouched, particularly through lack of local resources and the need of help from a central source. It should encourage co-ordination of effort and prevent the waste of money and effort in overlapping.

APART altogether from its direct activities, the existence of the Trust should encourage a more enlightened and generous attitude to the many problems which arise in regard to juvenile employment and leisure. It should lend powerful moral support to all agencies which are concerned with the education and recreation of young persons, whether in relation to industry or to eitizenship. It may provide a focus from which powerful support will be forthcoming for all efforts to deal wisely with the tragedy of juvenile unemployment, with excessive hours of work or with any other matters which hinder the normal development of citizens possessing the qualities of physical, mental and spiritual fitness and ideas of service which make a people great. The Jubilee Trust aims at dealing with the most erucial educational task of the time-that of guarding from the worst dangers of unemployment or unsuitable work at the most critical time of their physical, moral and mental development that large section of our young people between fourteen and eighteen years of age who are drifting into manhood and 